\title{
Utilização de apps para o ensino do efeito Doppler
}

\author{
Kelly Wendi da Silva ${ }^{1}$, Bianca Martins Santos ${ }^{2}$, Lídia da Rocha Silva ${ }^{3}$ \\ 1,2,3 Universidade Federal do Acre
}

Palavras-Chave: PHYPHOX; Frequency sound generator; Efeito Doppler.

\section{Introdução}

O ensino e aprendizado de física faz parte de um importante processo que possibilita ao indivíduo um olhar detalhado e uma melhor compreensão da natureza e do meio que o cerca. Ressalta-se a importância das aulas desta componente curricular (MOREIRA, 2018), proporcionar aos alunos atividades que desenvolvam o pensamento crítico, observação prática do conteúdo teórico no cotidiano, além de possibilitar e facilitar o manuseio de equipamentos tecnológicos.

Partindo do princípio que a física procura descrever os eventos físicos da natureza, torna-se necessário a criação de pensamentos mais sistematizados, de forma a detalhar e classificar os fenômenos. Neste sentido, o discente de física deve desenvolver estas habilidades para uma melhor compreensão dos assuntos estudados, deixando de ter o papel de ser um espectador, para tornarse responsável pelo processo e construção do próprio conhecimento.

Assim, o trabalho apresenta uma proposta de ensino para o tema do efeito Doppler, utilizado os aplicativos "Physical Phone Experments" e "Frequency Sound Generator". São propostas atividades experimentais que possibilitem aos estudantes perceberem o efeito Doppler associado ao som. Além da realização e comprovação experimental do fenômeno com a utilização de APPs, disponíveis através das plataformas digitais e que podem servir de suporte para favorecer a construção da relação ensino-aprendizagem.

\section{Metodologia}

O efeito Doppler por exemplo, pode ser mais elucidado quando analisado por um aplicativo. Uma vez que este fenômeno explica como o som emitido por uma fonte será percebido por um observado, quando um possui velocidade em relação ao outro, e nesse caso o observado e a fonte podem estar se afastando ou se aproximando. Com dois smartphones, um pode ser considerado a fonte emissora do som e o outro ser o receptor, o qual pode medir a frequência (KLEIN; et. al., 2014). Com esta abordagem, pode-se proporcionar a visualização do fenômeno com mais praticidade, de forma a promover o questionamento e o amadurecimento do pensamento crítico.

A proposta deste trabalho é o estudo do efeito Doppler, utilizando os aplicativos: "Frequency Sound Generator" e "Physical Phone Experments - PHYPHOX". O primeiro tem por função gerar e emitir frequências, desempenhando o papel da fonte sonora. Tais frequências podem ser reguladas a medida que o discente ou docente determinar com quais frequências necessita trabalhar. Já o segundo será usado para realizar uma análise do Espectro de Áudio, no qual é possível coletar dados como frequência $(\mathrm{Hz})$, a transformada de Fourier, entre outros, bem como limitar o tempo de coleta e apresentar a representação gráfica do som captado no próprio aplicativo.

Neste sentido, o trabalho propõe a aplicação do experimento com alunos do $2^{\circ}$ ano do ensino médio de uma escola pública de Rio Branco-Ac, que já tenham estudado o conteúdo de efeito Doppler. Tal experimento inclui os passos detalhados na Tabela 1.

Tabela 1 - Sequência didática para abordagem do tema em sala de aula.

\begin{tabular}{|c|c|}
\hline Etapa & Descrição \\
\hline $1^{\circ}$ & $\begin{array}{c}\text { Solicitar aos alunos que baixem os aplicativos "Frequency Sound Generator" e } \\
\text { "Physical Phone Experments - PHYPHOX", nos próprios smartphones (em casa). }\end{array}$ \\
\hline $2^{\circ}$ & Apresentar ensinar o manuseio dos aplicativos. \\
\hline $3^{\circ}$ & Dividir a turma em grupos de 4 alunos e explicar os procedimentos experimentais. \\
\hline $4^{\circ}$ & Coletar, analisar e discutir os resultados. \\
\hline
\end{tabular}

Fonte: Próprio autor.

O smartphone emissor do som deverá estar sobre uma superfície girante, com o aplicativo "Frequency Sound Generator" aberto e configurado, conforme a Figura 1, painel da esquerda.

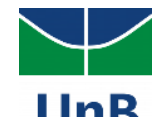


Observa-se que na primeira tela do aplicativo em questão, pode-se alterar a frequência. Tendo como opção, salvar a frequência utilizada no experimento.

No aplicativo PHYPHOX, deve-se selecionar a opção "Espectro do áudio", conforme indicado na Figura 1, painel da direita. Em seguida, pode-se definir o tempo de coleta (seta vermelha entre as últimas telas da Figura 1) e este aplicativo já estará configurado para uso, necessitando apenas de apertar o play (círculo azul penúltima tela da Figura 1).

Figura 1 - Print das telas dos aplicativos "Frequency Sound Generator" (esquerda) e "PHYPHOX" (direita).

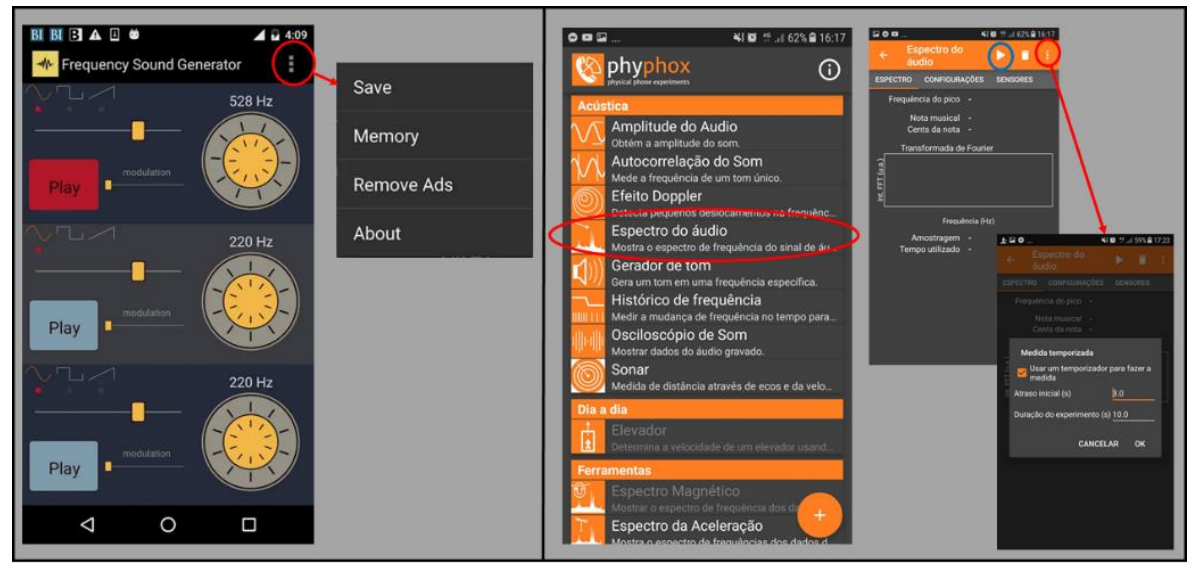

Fonte: Próprio autor, adaptado do Print das telas dos aplicativos.

Os procedimentos experimentais consistem em dar o play em ambos aplicativos e mantê-los em posições próximas conforme indicado na Figura 2. Na sequência, gira-se a plataforma, de preferência com o auxílio de um motor pequeno. No aplicativo PHYPHOX poderá ser avaliado a variação da frequência captada, quando comparada com o valor da frequência emitida.

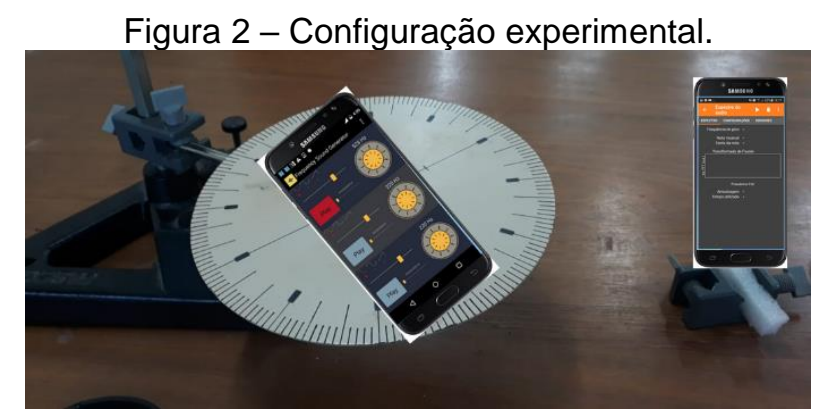

Fonte: Próprio autor.

\section{Resultados esperados}

Ao realizar os procedimentos experimentais propostos, almeja-se que o aluno identifique com o auxílio do próprio smartphone e da atividade em grupo entre os pares (aluno-aluno, alunoprofessor), o fenômeno estudado: o efeito Doppler. Espera-se avaliar se essa abordagem diferenciada pode proporcionar ao docente uma leitura e configuração de informações para potencializar e facilitar a compreensão do conteúdo entre os alunos.

\section{Referências}

KLEIN, P.; HIRTH, M.; GRÖBER, S.; KUHN, J.; MÜLLER, A. Classical experiments revisited: smartphones and tablet PCs as experimental tools in acoustics and optics. Physics Education, $v$. 49, n. 4, 2014.

MOREIRA, M. A. Uma análise crítica do ensino de Física. Estudos Avançados, v. 32, n. 94, 2018. 